\title{
An Examination of Tensions in a Hybrid Collaboration: A Longitudinal Study of an Empty Homes Project
}

\author{
Alex Gillett ${ }^{1} \cdot \operatorname{Kim}_{\text {Loader }}{ }^{1} \cdot$ Bob Doherty ${ }^{1}$ (I) $\cdot$ Jonathan M. Scott ${ }^{2}$
}

Received: 30 November 2016 / Accepted: 15 June 2018 / Published online: 29 June 2018

(c) The Author(s) 2018

\begin{abstract}
We analyse the tensions in a hybrid collaboration (specifically, a social alliance comprising three social enterprises and a local council) and how these are mitigated using boundary-spanning community impact, leading to compatibility between distinctive institutional logics. Our qualitative longitudinal study undertaken during 2011-2016 involved reviewing literature and archival data, key informant interviews, workshop and focus groups. We analysed common themes within the data, relating to our two research questions concerning how and why hybrids collaborate, and how resulting tensions are mitigated. The findings suggest a viable model of service delivery termed hybridized collaboration in which the inherent tensions from different institutional logics do not prevent success. Paradoxically, multiple logics are a basis for the partnership's existence, but the ability to achieve different and occasionally conflicting aims simultaneously (including "value for money" and local community benefit) can be difficult, resulting in tensions. We offer two novel insights. First, we highlight how social enterprise hybrids collaborate locally and in multi-organizational relationships. We found that the initial opportunity to collaborate was catalysed by the existence of shared objectives (to address housing need and unemployment). Pre-existing relationships between organizations, and the existence of synergistic capabilities also influence the choice of partners. Secondly, we identify how tensions arise (from differences in organizational size and available resources; ambitions for growth; and issues related to values and ethics), and are mitigated via several factors including the pre-existing relationships, allowing for regular "spaces of negotiation" between collaborators, the shared social mission, community social impact, the resulting public relations, and shared resources and knowledge.
\end{abstract}

Keywords Collaboration $\cdot$ Cross-sectoral $\cdot$ Social enterprise $\cdot$ Hybrid organizations $\cdot$ Social alliance $\cdot$ Tensions $\cdot$ Mitigation

\section{Introduction}

This article analyses the emergence and mitigation of tensions (stemming from organizations in different sectors having contrasting institutional logics) in a quadripartite

Bob Doherty

bob.doherty@york.ac.uk

Alex Gillett

alex.gillett@york.ac.uk

Kim Loader

kim.loader@york.ac.uk

Jonathan M. Scott

jonathan.scott@northumbria.ac.uk

1 The York Management School, University of York, York, UK

2 International Business and Economics, Newcastle Business School, Northumbria University, Newcastle, UK cross-sectoral collaboration involving three hybrid organizations and a local council, established as a public-hybrid collaborative partnership to tackle the problem of Empty Homes. Our longitudinal study demonstrates that tensions from opposing social and commercial logics can be compatible if they are part of the organizational goals. We, therefore, contribute to an emerging area of literature which examines what happens when hybrids collaborate (Nicholls and Huybrechts 2016; Ramus and Vaccaro 2017). Hybrids are defined as "organizations that exist in the intersections of two distinct spheres i.e. the public and the private" (Kickert 2001, p. 135). Indeed, Billis (2010) argues that they inherit characteristics from more than one sector. One form of hybrid organization is Social Enterprise (SE), defined as an organization that trades, not for private gain, but to generate positive social and environmental externalities (Santos 2012). Governments globally, as they adopt so-called 'austerity' policies, are increasingly looking towards social 
enterprises and other hybrid organizations to deliver social welfare services (Lyon 2012; Cornelius and Wallace 2010), which may raise various ethical issues, e.g. mission drift if such conduct is considered to be against their social objectives (Ramus and Vaccaro 2017; Teasdale 2010a). Therefore, SEs are required to face the conflicting institutional logics of social welfare and commercial objectives (Doherty et al. 2014). An example of hybrids delivering welfare services is the social housing sector where much of the responsibility for new social housing development has been devolved to hybrid Housing Associations (HAs) (Morrison 2016).

Whilst the extant literature tends to examine dyadic relationships in simple "buyer-seller" scenarios, we identified gaps: specifically a need for deeper information regarding how the management of more complex project-based collaborations work in practice, particularly where there are multiple collaborators with common goals but with differing priorities. Despite emerging research on how individual hybrid organizations manage their institutional logics (Besharov and Smith 2014; Battilana et al. 2015), few existing studies address how hybrids manage these logics in collaborations.

According to Hustinx et al. (2014), innovation between the state, the market and the third sector has heralded a new era of welfare hybridity in which social services are increasingly being delivered by new types of hybrid organizations blending the characteristics of more than one sector. Hence, there has been growing interest in cross-sectoral collaboration from policy-makers to solve wicked problems they cannot address alone (Bryson et al. 2015). These authors define cross-sector collaborations as the "linking or sharing of information resources, activities, and capabilities by organizations in two or more sectors to achieve jointly an outcome that could not be achieved by organizations in one sector separately" (ibid, p. 2), observing that a variety of labels can be attributed to these: including consortia, alliances and partnerships. Despite increasing collaboration between public and private sector organizations and social enterprises in the provision of housing and in tackling unemployment and homelessness, there is a dearth of literature on why and how hybrids collaborate with each other and with organizations in other sectors (Battilana et al. 2015), the resulting tensions and how these are mitigated.

Thornton and Ocasio (2008) propose that the institutional logics perspective provides insight into the contradictions that emerge in beliefs, values, ethics and practices. There is very limited research on why these different outcomes arise at both organizational and field level. Thornton and Ocasio (1999) define institutional logics as 'socially constructed historical patterns of material practices, assumptions, values, beliefs and rules' (1999, p. 804). Institutional logics represent culturally reinforced rules of action that have important roles in processes of organizational identity formation, sense-making and legitimation (Suchman 1995; Thornton 2004). Nicholls and Huybrechts (2016, p. 702) suggest that logic dominance would be expected to reflect the power configurations within relationships, a view consistent with Thornton and Ocasio (1999) who argue that conflict between logics in inter-organizational relationships is a temporary process in transition to a new equilibrium where the more powerful actor's preferred logic will be imposed on the relationship.

The logics to which we refer to in this study include the market/commercial logic to achieve business success, and the social welfare/community logic to create social value (Pache and Santos 2012; Santos et al. 2015). Research provides different conclusions regarding the results of managing multiple institutional logics. Some scholars associate multiple logics with contestation and tension (Battilana and Dorado 2010), others describe the co-existence and blending of logics (Binder 2007), some argue that the presence of multiple logics can result in organizational failure (Tracey et al. 2011) and finally multiple logics can actually lead to new innovation (Jay 2013).

Whilst Empty Homes initiatives (publicly funded schemes that aim to restore the use of uninhabited dwellings) are commonplace in the United Kingdom (UK), the collaborative model adopted in our empirical example is particularly novel. Nicholls and Huybrechts (2016) propose that there is a dearth of longitudinal studies investigating cross-sector collaborations, particularly where the inter-organizational relationship is unbalanced with a more powerful partner. Our analysis of a collaborative venture involving multiple hybrid organizations of different sizes suggests a viable model of service delivery that we have termed hybridized collaboration in which the inherent tensions are mitigated and do not emerge as barriers to success.

Our empirical 6-year longitudinal study, undertaken during 2011-2016, adopted a qualitative approach involving a review of the literature and archival data, and three phases of primary data collection involving key informant interviews, workshop and focus groups. Our unit of analysis is a collaborative partnership of organizations operating in Northern England. This collaboration, which we identify as a social alliance (Lyon 2012), was of interest because of the innovative way in which it uses the Empty Homes grant to achieve additional benefits for local communities. The collaboration addresses unemployment and work training, as well as meeting the core objectives of bringing empty properties back into use for people in need of housing, and reducing anti-social behaviour associated with derelict/empty buildings. Paradoxically, multiple logics are a basis for the partnership's existence; however, the ability to achieve different and occasionally conflicting aims simultaneously (including "value for money" and local community benefit) can be difficult, resulting in intra-partnership tensions. Tensions in the 
hybridized collaboration arise from differences in organizational size, available resources, ambitions for growth, and issues related to values and ethics. However, these tensions are mitigated via a series of factors including pre-existing relationships, allowing for "spaces of negotiation" between collaborators, the shared social mission, boundary spanning social impact, and the resulting public relations (PR) (external legitimacy), and shared resources. Thus, our study contributes to the growing body of research on both hybrid organizing and cross-sector collaborations involving multiple logics.

This article is structured as follows. We commence with Sect. "Literature Review", which reviews literature relating to social enterprise and hybridity, cross-sector collaboration and social alliances. The extant literature distinguishes between the public, private and third sectors, but also identifies the existence of 'hybrid' organizations which follow logics from more than one sector, and that these organizations can be characterized by different degrees of such hybridity. Whilst previous research has emphasized the benefits of social alliances between partners within - and acrosssectoral boundaries, there is a dearth of published work to address the challenges of managing different institutional logics in such collaborations. The role of individuals within organizations is considered important to address such challenges. Hence people who interact between organizational, geographic and sector boundaries to catalyse partnership formation are 'bridging agents' who can turn complexity and ambiguity from different institutional logics into collaborative opportunities and constraints. We conclude our literature review by defining two research questions in relation to the collaborative Empty Homes project.

Section "Methodology" provides an overview and justification of our research design, methodology, and methods. Doing so enabled us to address the gaps identified in the literature review to investigate the ways in which cross-sectoral social alliances-including hybrids - manage the tensions of their hybridity to achieve social value successfully.

Section "Findings" comprises the findings and analysis of the study. We categorize the four partner organizations to demonstrate their distinctive and differing nature and institutional logics. We then explore the dynamics of managing the collaborative relationships in our case, a 'hybrid of hybrids' (a hybrid collaboration comprising different types of hybrid organization) including emergent tensions. Specifically, we examine how these were mitigated-including discussion of the role of individual decision-makers within the collaborating organizations. We also summarize these findings in tabular form (Table 5) to provide an overview of challenges, tensions, mitigations and outcomes in the studied collaboration. Section "Discussion" comprises a discussion of institutional logics and their interplay and interaction with the emergence and mitigation of tensions within the hybrid collaboration, leading to several proposed future research directions. Section 6 completes the article with a conclusion and recommendations for policy and practice.

\section{Literature Review}

An important component of our grounded theory-based research design was a critical review of the literature to identify important areas of the extant literature that had relevance to our own data and enabled us to make sense of our case. In particular, we found a growing number of prior studies relating to hybrid organizations and SEs, including the existence of tensions stemming from their different objectives (social and financial). Furthermore, we were interested in collaborative working involving government, and identified the social alliance as a collaborative form relevant to our study. We now synthesize the literature, beginning with an explanation of SEs and hybrid organizations.

SEs' dual mission of financial sustainability and social purpose (Teasdale 2010b) has blurred and fluidized the boundaries between the conventional private, public, and non-profit sectoral categories. By definition, hybrids are the offspring of two different species (OED 2010) and in the organization and management literature the term has been employed to describe organizations that span institutional boundaries (Brandsen and Karré 2011; Jay 2013; Pache and Santos 2012; Smith 2010) and operate in multiple functional domains (Ruef 2000). SEs are prime examples of hybrid organizational forms because they span the boundaries of the private, public, and non-profit sectors (Tracey et al. 2011) and face conflicting social and commercial institutional logics which can create both tensions and opportunities (Doherty et al. 2014; Pache and Santos 2012). Hybrid organizational forms draw upon at least two different sectoral paradigms, logics and value systems and, in the case of SEs, relate to the emergence of novel institutional forms that challenge traditional conceptions of economic organizing (Wilson and Post 2013). Mars and Lounsbury (2009) suggest that it is inaccurate to assume that market logics will exist in direct opposition to the social logic in the context of emergent hybrid forms. They also ascertain that, over time, one logic can however establish itself as more powerful and dominant, in turn leading to opposing logics (ibid). At the individual organizational level, hybrids have developed a range of mechanisms to mitigate the tensions such as: creating complementarities by using social impact to differentiate and add economic value (Hockerts 2015), use non-financial rewards based on social mission to motivate staff (Austin et al. 2006), and implement regular spaces for negotiation to discuss tensions (Battilana et al. 2015). Furthermore, Smiddy (2010) suggested that the hybrid nature of SEs may work 
positively to facilitate collaboration and access resources with organizations across the public, private, and "third" sectors, although Simmons (2008) cautioned that all members of a partnership involving SEs must be constructive and agree how to balance the tensions between the social and entrepreneurial goals.

In this article, we draw particularly on the distinctions between the public, private and third sectors and the assumption that categories of organizations manifest generic structural features and characteristics that are in some way "pure" and indicative of these distinct and recognizable sectors (Billis 2010; Somerville and McElwee 2010). Such categories are presented as idealized forms in which organizations, through alignment with categorical logics and discourse, acquire legitimacy. To elaborate, Billis (2010)—which informs our analysis in Sect. "Findings" of the articlepresents organizational templates for the categories of (1) private, (2) public and (3) non-profit organizations. These templates are respectively guided and characterized by: (1) market forces to maximize financial return, owned by shareholders, governed according to size of share ownership, and generate revenue from sales and fees; (2) the principles of public benefit and collective choice, owned by citizens and the state, and resourced through taxation; and (3) social and environmental goals, are owned by members, governed by private election of representatives, staffed by a combination of employees and volunteers and generate revenue from membership fees, donations and legacies (ibid). Specifically, non-profit distributing organizations are legally prohibited from distributing any residual "earnings" to those with a managerial or ownership interest (Hansmann 1980).

Our analysis of the collaboration's participants (see Sect. "The Operation and Management of the Collaboration") is also informed by Billis' (2010) assertion that there are different degrees of hybridity: first, entrenched most often occurs when income, either from grants or other sources, is sufficient to sustain management hierarchies within the organization; second, shallow occurs when the organization begins to employ staff funded from external sources. third; organic refers to unplanned hybridity; fourth, enacted refers to organizations established deliberately as hybrids.

Studying collaboration is important because reductions in budgets for welfare services have resulted in local governments being called upon to partner with organizations across sectors and civil society to solve public problems they cannot address on their own (Bryson et al. 2015). There are advantages for participants collaborating within cross-sector alliances and networks, not least the collective size and capabilities achieved by pooling resources, which might be attractive to funding bodies, whilst remaining flexible and small at the independent level. Success partly depends of course upon the collaborators' ability to choose the right partners, and then to use and manage partners effectively despite having different institutional logics (Davies 2009).

Several other studies have also examined the performance of cross-sector collaborations (Andrews and Entwistle 2010; Cairns and Harris 2011; Hodge and Greve 2007; Van Tulder et al. 2016). Bryson et al.'s (2015) comprehensive review of the field highlighted the commonalities between the different theoretical frameworks, including the influence of antecedent conditions on collaboration effectiveness (e.g. the institutional environment: reduced welfare funding, public issues and windows of opportunity due to policy change). In addition, they identified factors relating to: power or resource asymmetries (collaborative planning); goal consensus, trust, and inclusive processes; formal agreements; initial pre-existing relationships; shared understanding of the problem, effective communication; internal and external legitimacy; leadership; collaborative structures to develop norms and practices; authoritative texts (e.g. mission statements, memoranda of understanding); ambidexterity; attitudes and competencies; accountabilities and outcomes (ibid). While Bryson et al. (2015) explore sources of collaborative tensions, there are gaps in the literature including: how collaborations mitigate the tensions and an extant focus on public-private partnerships rather than multiple crosssectoral or hybrid organizations.

Manning and Roessler (2014) discuss the importance of 'bridging agents' to the agenda-setting, formation, and longterm development of cross-sector partnerships between government, business and civil society organizations to address complex issues such as economic development. These bridging agents are individuals who interact between organizational, geographic and sector boundaries to catalyse partnership formation. They can turn complexity and ambiguity from different institutional logics into collaborative opportunities and constraints. Research on inter-organizational relationships suggests that such relationships may fail because the partners have unequal power and draw upon distinctive institutional logics (Galaskiewicz and Colman 2006; Hardy and Phillips 1998).

Collaborations between government and organizations from other sectors driven by objectives centred on addressing social and/or environmental issues are sometimes referred to as social alliances, and typically involve the sharing of resources, knowledge and capabilities. Notwithstanding Selsky and Parker's (2005) literature review, most previous social alliance literature investigated business and non-governmental organizations' (NGOs) collaborations (Austin 2000; Berger et al. 2006; Gray and Stites 2013; Horton et al. 2009; Kolk and Lenfant 2015; Sakarya et al. 2012; Seitanidi et al. 2010; Seitanidi and Crane 2014). Our study is a quadripartite partnership across multiple sectors, comprising three hybrids (of which two are SEs) and a local council. Social alliance development is a 
potentially superior strategy for SEs to acquire resources, gain access to markets and serve the needs of beneficiaries (Austin 2010). Social alliances range from, on the one hand, formal cooperative structures such as joint ventures, partnerships, licensing (Austin 2010), and social franchising (Tracey and Jarvis 2007) to, on the other hand, less formal mechanisms such as sharing ideas freely and allowing others to scale up an innovative approach (Lyon and Fernandez 2012). The outcomes of effective social alliances include asset accumulation, market expansion, and wider social impact which, in turn, foster greater mission fulfilment. The correct choice of partner in a social alliance, however, is crucial as legitimacy with stakeholders is influenced by the reputation of the partner (Austin et al. 2006; Moizer and Tracey 2010).

Previous research has emphasized the benefits of social alliances between partners within-and across-sectoral boundaries but not the challenges of managing different institutional logics (Austin 2010; Gillett et al. 2016). Hybrids are hence well placed to collaborate with non-profits and with the private sector corporates (Di Domenico et al. 2010). Alliances are also useful when bidding for public service delivery contracts as the resource requirements of large service delivery agreements are beyond those of individual SE hybrids.

Building on the gaps identified in the literature reviewed above, we investigated the ways in which cross-sectoral social alliances-including hybrids-manage the tensions of their hybridity to achieve social value successfully. To fulfil this broad aim, we defined the following research questions in relation to the collaborative Empty Homes project:

RQ1 Why and how do hybrids collaborate?

RQ2 How are tensions in such collaborations manifested and mitigated?

The main contribution of our study relates to novel insights into both the theoretical and practical aspects of how hybrids collaborate at a local level and on multi-organizational relationships, derived from investigation over a 6-year period.

\section{Methodology}

Having presented our literature findings and research questions, we now outline our research design (a qualitative empirical study), and explain our methods of data collection and analysis.

\section{Research Design}

The qualitative empirical study undertaken between 2011 and 2016 involved a critical review of the literature and archival data, key informant interviews, workshop and focus groups.

\section{Explanation of Method}

\section{Data Collection}

Data were collected via regular interviews and focus groups with key informants from the four participant organizations during the lifetime of the Empty Homes collaboration. These organizations comprised a housing association (Coast), a social housing provider (Urban), a housing trust (Rural) and a borough council (Council). The collaboration was an initiative funded by the Homes and Communities Agency's (HCA) Empty Homes Grants Programme (October 2010-March 2015) involving three annual funding tranches from 2010 to 2012. Tables 1, 2 and 3 show that much data were collected at both the beginning and end of the Grant period. Hence, we sampled intensively between 2011 and 2012 (Phase 1: Table 1) then in 2014 around the middle of the third funding tranche (Phase 2: Table 2). With the HCA's Empty Homes funding ending in March 2015, we collected data in February and March, and again in September 2015 approximately six months after funding ended (Phase 3: Table 3). The timings were intentional to enable respondents
Table 1 Details of interviews and focus groups: research phase 1 (early phase-initial funding tranches for Empty Homes work)

\begin{tabular}{|c|c|c|c|}
\hline Date & Method & Organizations & Participants \\
\hline Dec 2011 & Semi-structured interview & Urban/urban (trading) & $\mathrm{CEO}$ /director \\
\hline Apr 2012 & Focus group (semi-structured) & Urban/urban (trading) & $\begin{array}{l}\text { CEO/director } \\
\text { Director of finance } \\
\text { Development manager }\end{array}$ \\
\hline July 2012 & Semi-structured interview & Council/coast & $\begin{array}{l}\text { Empty homes officer } \\
\text { Head of tenant services }\end{array}$ \\
\hline Aug 2012 & Semi-structured interview & Urban (trading) & Craft-coordinator/director \\
\hline Dec 2012 & Semi-structured interview & Coast & Service charge manager \\
\hline Dec 2012 & Semi-structured interview & Rural & Project manager 1 \\
\hline
\end{tabular}


Table 2 Details of workshop focus group: research phase 2 (mid phase-continuation of Empty Homes funding and planning for the final year of funding)

\begin{tabular}{llll}
\hline Date & Method & Organizations & Participants \\
\hline May 2014 & Workshop discussion/focus group (semi-structured) & Urban & Development manager craft-coordinator/director \\
& & Urban (trading) & Head of tenant services \\
& Coast & Project manager 2 \\
& Rural & Senior area manager \\
& HCA & Housing services team leader \\
& Council & Enforcement officer \\
\hline
\end{tabular}

Table 3 Details of interviews and focus groups: research phase 3 (final phase-Empty Homes funder's deadline, critical reflection on the collaboration)

\begin{tabular}{llll}
\hline Date & Method & Organizations & Participants \\
\hline February 2015 & $\begin{array}{l}\text { Informal discussions at an all-day } \\
\text { national Empty Homes conference }\end{array}$ & $\begin{array}{l}\text { Urban } \\
\text { Urban (trading) } \\
\text { Rural }\end{array}$ & $\begin{array}{l}\text { Development manager craft-coordinator/director } \\
\text { Project manager 3 }\end{array}$ \\
& Semi-structured interview (a) & Rural & Project manager 3 \\
March 2015 & Focus group (semi-structured) & Urban/urban (trading) & CEO/director \\
Sept 2015 & & & Development manager craft-coordinator/director \\
& Semi-structured interview (b) & Rural & Project manager 3 \\
September 2015 & Semi-structured interview & HCA & Senior area manager \\
September 2015 & Observation of participants at an & Urban/urban (trading) & CEO/director \\
June 2016 & externally organized Empty Homes & Rural & Development manager craft-coordinator/director \\
& workshops & HCA & Project manager 3 \\
& & & Trustee \\
& & & Senior area manager \\
\hline
\end{tabular}

to have sufficient time to reflect critically on several months of activity, and any necessary internal debriefing to have taken place and for financial information to have been processed. At all phases of data collection, discussion with participants focussed on our two research questions, as well as what had happened since the previous discussions had taken place.

Key Informants were selected by "theoretical sampling" (Corbin and Strauss 1990; Glaser and Strauss 1967), representing a cross section of stakeholders with decision-making responsibility within the partnership. We also conducted a workshop in May 2014 to present (and obtain participant feedback on) emergent interim findings. The workshop was attended by representatives of all organizations involved in the partnership but (due to staff turnover and availability) the group of representatives comprised three who had not met the researchers before, and three participants who had previously been interviewed. Follow-up questions and answers were conducted via email. Newsletters and other useful information were also periodically sent to the researchers via email by Urban and Rural. Additional data sources included partners' websites, reports, and archive of internal documents and communications relating to Urban.

With participants' permission, audio recordings were made of all the interviews and focus groups, and the resulting files were then typed-up verbatim for analysis. The discussion at the Phase 2 workshop focus group in May 2014 was summarized manually by members of the research team due to a technology failure which meant that a verbatim recording was not possible.

The decision to undertake semi-structured interviews and focus groups as our main means of collecting data was for methodological as well as practical reasons. Semistructured interviews enabled us to talk at length with individuals without interruption, and in private. This approach was particularly useful in the earlier stages of our study in which we were developing rapport with the organizations and individuals, as well as learning about them. For these reasons, four out of six data collection events at Phase 1 were semi-structured interviews. The exceptions were the April 2012 focus group (3 participants) and the July 2012 interview in which two participants were interviewed together, because of the participants limited availability. However, a positive outcome of the group-based approaches was the interaction and dialogue between the participants, who elaborated upon points each other raised and discussed issues that they might not have done had their colleagues not raised the point. This worked well with participants who were used to working together closely. 
Following Phase 1, we decided to provide work-in-progress findings to our participants and to open up discussion between them to help shape the direction of the study. A workshop was held involving representatives of the various collaborative partners and the regulatory body (HCA).

For the final phase of our project (Research Phase 3), we conducted semi-structured interviews with Rural and with the HCA because they each provided one participant, and because they were more comfortable discussing some of the more critical aspects in one-to-one interviews rather than in a forum with the other organizations. On the other hand, a semi-structured focus group was considered more effective when sampling Urban, again due to the rapport between the participants and because of their availability.

A further approach was to attend two Empty Homes workshops, which were organized by a third-party research team based at a different university, also investigating the Empty Homes initiative nationally, but focussing more upon its social outcomes. Due to their generosity, we were invited to attend these events: which enabled us to collect useful data including the latest news from the UK government and Civil Service about the funding situation for Empty Homes schemes, statistics and findings from analysis about Empty Homes initiatives, as well as an opportunity to interact informally with our participants. For example, an important outcome was being introduced at the February 2015 event to the latest Project Manager of Rural who had taken over the role since the 2014 Workshop. We provided a copy of the project interim/Workshop report to him, and a few days later arranged a semi-structured interview, which was followed up 5 months later with a second interview.

\section{Data Analysis}

Analysis focussed on examining: (1) profiles of the individual participant organizations; and (2) the collaborative process. We analysed themes within the accounts of our interviewees and sought commonalities and interrelationships (where possible) between the research questions. Analysis was undertaken by individual co-authors, with notes on sub-themes being compared and agreed. Findings were compared with those within the existing literature followed by critical face-to-face or online discussions between co-authors to compare and contrast the emergent findings from our hybrid collaboration with those reported elsewhere. Findings were triangulated by presenting back to the participants, principally during the May 2014 workshop, but also through the resultant interim/workshop report document, and via discussions in the interviews and focus groups. Additionally, work in progress was presented at academic events.

We researched theory for an explanatory framework following Eisenhardt's (1989) recommendation to ask ourselves 'what theory is this similar to? What does it contradict and why?' Eisenhardt (1989) claims that linking to existing theory in this way enhances the internal validity, generalizability and general level of theory building from case research. Fundamental to our study were the work of Billis (2010), Besharov and Smith (2014) and Bryson et al. (2015), which helped us to conceptualize the nature of hybridity on the collaboration. Taken together, the identified themes provided a basis for our framework for managing and mitigating tensions, explained later in the article in Table 5.

\section{Findings}

Having explained our theoretical underpinning, purpose and methodology, we now present our findings. Firstly, as a contextual background to our analysis, below we briefly profile the individual participants to demonstrate and explain the Empty Homes Project collaboration as a hybrid collaborative partnership. Secondly, we explain the nature of the collaborative relationships within the partnership, analysing why and how it operates, to address RQ1. Our analysis of the hybridized collaboration determined a series of challenges and tensions that arose, predominantly as a result of the differences in organization size and available resources, and the differing priorities and logics of the participants. However, we found that these emergent tensions were mitigated via a series of factors which ultimately enabled the collaboration to succeed, thus addressing RQ2. Since institutional logics emerged later in our analysis, we return to a consideration of them in our discussion.

As the study focuses on an examination of collaborative dynamics and management, particularly participant diversity, we first analysed and categorized the four partner organizations by employing Billis' (2010) core elements as a framework to determine their sector and to demonstrate their distinctive and differing nature and institutional logics. Thus the Housing Association Coast was established in 2001 as part of a voluntary stock transfer from the council (Coast 2013). Coast has its roots firmly in the state (public) sector but now exhibits features associated with both private and non-profit organizations: namely its significant reliance on borrowing from the commercial sector, its board structure, and the emergent diversification of its activities including welfare, regeneration and commercial operations. The social housing provider, Urban, established in 1987 as a community organization to tackle homelessness, also provides training through property renovation, which soon developed into a building services trading arm, now a wholly owned subsidiary, confirming Urban's status as a SE. The housing trust, Rural, exhibits many similar features to Urban. Established more recently in 2000, it is much smaller but is also a community-based organization, addressing youth 
homelessness and developing construction skills through property renovation. It also provides building services to the community although not currently through a formal trading company. The fourth participant, the local authority (Council), is responsible for housing and empty homes, reflecting the core elements of a public sector organization.

Furthermore, Billis' (2010) degrees of hybridity enabled us to determine that the collaborative project comprises one state and three hybrid organizations of which one is an entrenched, enacted hybrid and two are entrenched, organic hybrids. The developments by Coast since its establishment in 2001 have produced a shift to hybridity, in common with other housing associations as previously determined by Mullins and Pawson (2010), and its creation by stock transfer is enacted (Czischke et al. 2012). Moreover, our findings support Mullins and Pawson (2010) in that Coast is closest to Billis' (2010, p. 57) public/private/third zone. Urban's social and commercial activities confirm its status as a SE and, therefore, a hybrid organization, but one which has developed organically rather than enacted. Its inception as a community organization, with trading interests, place it in two sectors, third, and private, and its reliance on a mix of funding suggest it is entrenched. The third hybrid, Rural, exhibits many similar features to Urban by exhibiting hybrid features, sitting within Billis's (2010) third / private zone, and being similarly organic and entrenched. Hence, both Urban and Rural prioritize both providing training and employment opportunities for young unemployed individuals and reducing homelessness i.e. the social welfare logic. The fourth participant, Council, is the only non-hybrid.

Therefore, a novel aspect of this study is to examine and attempt to understand the dynamics of managing a collaborative relationship-including emergent tensions and how these are mitigated-involving not only different types of organizations, but especially different types of hybrid organization. Table 4 provides an overview of the organizations within the hybrid partnership, including a comparison of organizational 'types', incorporating Billis's (2010) typology.

\section{The Operation and Management of the Collaboration}

We now present and discuss the findings from our case in relation to our first research question 'Why and how do hybrids collaborate?'

The Empty Homes grant presented the initial opportunity to collaborate but it was an informal recommendation to

Table 4 Analysis of participant organization types

\begin{tabular}{|c|c|c|c|c|}
\hline \multirow[t]{2}{*}{ Core Element } & \multicolumn{4}{|l|}{ Participant organization } \\
\hline & Council & Coast & Urban & Rural \\
\hline Ownership & Citizens & $\begin{array}{l}\text { Private company lim- } \\
\text { ited by guarantee, } \\
\text { no share capital }\end{array}$ & $\begin{array}{l}\text { Voluntary housing group (Industrial } \\
\text { and Provident Act) } \\
\text { Community interest company } \\
\text { Private company limited by guar- } \\
\text { antee }\end{array}$ & $\begin{array}{l}\text { Private company, limited by guar- } \\
\text { antee, no share capital }\end{array}$ \\
\hline Governance & Elections & $\begin{array}{l}\text { Board with tenant, } \\
\text { local authority and } \\
\text { independent repre- } \\
\text { sentation }\end{array}$ & Voluntary Board of Directors & $\begin{array}{l}\text { Managed by trustees } \\
\text { Independent monthly audit }\end{array}$ \\
\hline Operational priorities & Local public services & $\begin{array}{l}\text { Social landlord } \\
\text { Regeneration } \\
\text { Welfare } \\
\text { Commercial letting }\end{array}$ & $\begin{array}{l}\text { Provider of housing for young } \\
\text { people } \\
\text { Training provider } \\
\text { Building services }\end{array}$ & $\begin{array}{l}\text { Provider of housing for young } \\
\text { people } \\
\text { Training provider } \\
\text { Personal development } \\
\text { Building services }\end{array}$ \\
\hline Human resources & $\begin{array}{l}\text { Paid employees } \\
\text { Elected members }\end{array}$ & Paid employees & $\begin{array}{l}\text { Paid employees } \\
\text { Volunteers } \\
\text { Trainees }\end{array}$ & $\begin{array}{l}\text { Paid employees } \\
\text { Volunteers } \\
\text { Trainees }\end{array}$ \\
\hline Other resources & $\begin{array}{l}\text { Taxes } \\
\text { Fees }\end{array}$ & $\begin{array}{l}\text { Commercial loan } \\
\text { Grant } \\
\text { Asset sales } \\
\text { Rental income } \\
\text { Reserves }\end{array}$ & $\begin{array}{l}\text { Grants } \\
\text { Trading income }\end{array}$ & $\begin{array}{l}\text { Grants } \\
\text { Trading income }\end{array}$ \\
\hline Type & State & $\begin{array}{l}\text { Public/private/third } \\
\text { Hybrid } \\
\text { Enacted } \\
\text { Entrenched }\end{array}$ & $\begin{array}{l}\text { Social enterprise } \\
\text { Third/private } \\
\text { Hybrid } \\
\text { Organic } \\
\text { Entrenched }\end{array}$ & $\begin{array}{l}\text { Social enterprise } \\
\text { Third/private } \\
\text { Hybrid } \\
\text { Organic } \\
\text { Entrenched }\end{array}$ \\
\hline
\end{tabular}


tackle unemployment (or 'worklessness')—a social objective-that was especially crucial as all the participants were already attempting to address this issue and, therefore, had an interest in being involved (Dew 2009; Jones and Dunn 2007; Martello 1994). The existence of pre-existing relationships between the partners provided a further impetus. Although all partners agreed that the partnership developed "by chance", rather than by design, the institutional environment, just after the election of a new Coalition Government in 2010 and its desire to engage with civil society, favoured the contribution of a social enterprise being commissioned to carry out the renovation work rather than a traditional builder. Conversely, other studies suggested that cross-sector collaboration partnerships were driven by external policy drivers (for example, Cairns and Harris 2011). Although the partnership was formed in response to external funding that was available for housing, the partner organizations generated two novel ideas, creating 'value added' (not specified by the funder): (1) tackling worklessness, and (2) working in partnership to achieve that. The two SEs, Rural and Urban, had more experience, competencies and capabilities in training young 'hard to reach' people than did their two partners on their own. However, Council and Coast had knowledge, buying power, size and 'registered housing provider' status (in the case of Coast) and also good interpersonal relationships with key personnel at the regional branch of the HCA, the main funding body (allocated via its dedicated Empty Homes programme).

As identified, various pre-existing relationships and links between the partners were pertinent: for example, Coast was established by the transfer of Council's public housing stock; Urban was instrumental in establishing Rural; Rural also receives financial support from Council; and links exist at Board level. The Empty Homes partnership appears to have developed organically: rather than any one organization trying to diversify itself into a "one-stop-shop", the participants extended their co-operation to form a larger, informal organization in which each partner adds value to the overall offering. This resonates with the concept of synergy, a "mutual advantage perspective on cross-sector partnership working" (Cairns and Harris 2011, p. 315), i.e. each organization can achieve its own objectives better than it could alone (Huxham 1993). This finding is typical of cross-sector partnerships and is an important theme in the SE management literature (Doherty et al. 2014). This project was the first to bring together these four specific organizations, but the previous connections were important to reduce perceived risks and increase the potential for success. However, prior experiences and knowledge were positive: Urban's history and positive reputation-as well as successful previous interactions - were cited by Coast and Council as being highly influential to their inviting Urban and Rural to participate. Urban recognized that they were in a strong position: 
If we were an embryonic social enterprise with a year's track record I don't think Coast would have looked at us. I think because we've got a twenty-year portfolio of work with marginalized clients and delivering all these projects is a real good selling point for Coast...it helps their bid.

(CEO, Urban, 2011)

A (previous) interpersonal relationship with an employee of the funding body, the HCA, who had formerly been employed by Council and who had intimate knowledge of the local area was deemed by the Development Manager of Urban to have been important for the formation of the partnership. Further, the CEO of Urban identified the active "let's do it" attitude of Coast, which contrasted to his previous experiences working with housing associations. Additionally, both CEO and the Funding Officer of Urban, the Tenant Services Manager of Coast, and the Project Manager of Rural each identified the proactive behaviour of Council's Empty Homes Officer as being significant:

Basically, it started because [] came in to discuss about some empty properties that we had over in [] where they were causing real problems... \{Council's Empty Homes Officer\} came in and you could tell he was going to do something rather than in the past where it's just been 'oh pass it over' and three months later see what happens and ask again 'what's actually happened with that empty property?' So we knew that we could come and do something together.

(Head of Tenant Services, Coast, 2012)

With reference to our literature findings (see Sect. "Literature Review") these two individuals are, therefore, "bridging agents" (Manning and Roessler 2014) because of their important role as catalysts to the formation of the partnership, and as we shall now explain, also helped to mitigate some of the tensions that emerged within the partnership.

\section{Management Processes: The Emergence and Mitigation of Tensions}

Next we analyse the collaboration in relation to our second research question 'How are tensions in such collaborations manifested and mitigated?'

\section{Organizational Differences}

Attributes such as trust, openness and honesty have been identified as contributing to successful partnerships, since they can help to minimize counter-productive "inter-organizational distance" (Simmons 2008, p. 296). However, unequal knowledge and experience amongst partners can create challenges. It may seem counterintuitive that a large organization such as Coast had not developed its own internal capacity to deal with the challenges of unemployment and the associated problems of restricted opportunities for training and education.

The Funding Officer of Urban perceived that many large housing associations did not consider themselves to be SEs, particularly those formed as "arm's length" companies to take over council housing stock. Whilst Coast was an exception, it was not operating in the same way as a more traditional social enterprise, such as Urban. Both Rural and Urban perceived a cultural legacy from its time as a former housing department of Council and inferred that the shared history and closeness between the two larger organizations in the collaborative partnership at times made it difficult for the smaller organizations to have as much influence as they would like, which created tensions.

The funding for Empty Homes was initially awarded incrementally and unpredictably. This created challenges for the two smaller SEs who did not have the resources to retain so many trainees and this, in turn, created capacity problems for the partnership when bidding for more work. The larger partners also faced increasing financial pressures. Yet, because of the efforts of individuals involved in decision-making (most of whom were interviewees in our study), the partnership appears to have managed these challenges collectively and effectively, delivering its community benefit objectives:

All have a vested interest to deliver their service, Urban has done some things at a loss, but the social outcomes have been achieved. Coast, and Council have had budget pressures - so they have focussed on 'quick wins' and problematic ones (empty homes). All have tensions.

(Workshop Discussion, Senior Area Manager of the HCA, 2014)

New tensions emerged and others were magnified as the collaboration developed over time, and they became evident as "key" individuals moved on and the scale of the Empty Homes work increased resulting in changes to working methods and culture. For example, both smaller SEs mentioned the challenge of meeting Coast's expectation that they could respond speedily to publicity opportunities-an indication of the project's early success. These capacity and resource-based tensions were particularly pronounced for Rural, the smallest partner. However, an important aspect in developing the relationship, for Coast, was learning to understand and work with smaller SEs that did not have the same resource base:

That's been a learning curve for us...small enterprises want to get big but usually grow over a period of time, not like in a three-month period. 
(Head of Tenant Services, Coast, 2012)

A further change to emerge was a growth in bureaucracy. The collaboration initially consisted of a steering group which met weekly and all partners needed to agree on decisions. The arrangement was informal with no legally binding contract. However, by 2015 the smaller organizations, Urban and Rural, rued the loss of informality which had previously worked well: processes had become slower, less dynamic, and involved more bureaucracy, developments that were perceived as negative and the cause of tensions between the participants:

Maybe it doesn't feel as dynamic as it once did butand maybe that's a growing pain of the partnership. ...things are more formal, or slower, yet Coast will still grumble when outputs aren't met. Even though sometimes it's their offices haven't sorted the gas or electricity out so you can't sign a house off. I mean it's created another level of tensions.

(CEO, Urban, 2015 Focus Group)

The managers of the smallest partner, Rural, were critical throughout the project about the demand to attend frequent long meetings (Project Manager 1, 2012; Project Manager 3, 2015a; 2015b), yet Urban's management reflected that they were useful initially, and provided a space for overcoming tensions. However, as the scale of Empty Homes work being undertaken by Coast grew, the dialogue had become diluted:

The informal process was good because you'd go to a meeting, you'd bring a point up, you got a decision then or you got a decision the day after. Now it's - it's this bureaucratic machine that - that seems to take forever to give you a decision on things.

(Craft-coordinator, Urban/Director, Urban (Trading), 2015 Focus Group)

The perceptions of the participants from Rural illustrate how the other organizations placed different emphasis on the quantifiable outcomes and financial objectives of the Empty Homes initiative, whereas Rural appears to have placed greater weighting on the training element of the long-term unemployed youth (social welfare logic). These observations highlight the challenges of operating within a collaboration of hybrid organizations to achieve hybrid social and financial objectives, when different organizations prioritize things in a variety of ways due to differing missions.

Rural's views of the decision-making within the collaboration indicated frustration at the difficulty and timing of decisions, and a perceived dominance by the other organization due to its size:

I think sometimes we're treated as though we're a bit, you know, we're the small partner: 'We'll tell you what to do and how to do it and when to do it. And we'll give you just enough information, but we won't let you make too big, important decisions, 'cause they're ours.

(Project Manager 1, Rural, 2012)

However, at the third phase, Project Manager 3 saw their contribution more positively:

Rural were brought in because we've got the charity aspect. We've got that angle on things, we do things completely different to the likes of, we're a smaller scale version of Urban.... We're all about the training aspect of things. And our lads may take slightly longer to do the work because they're training, that's what they do but we still get the same results in the end.

(Project Manager 3, Rural, 2015a)

Project Manager 3 believed changes in expectations within the collaboration had occurred in 2014, 12 months prior to our interview and around the time he took over. $\mathrm{He}$ thought that some of the individual people involved had been replaced, and the quantity of Empty Homes work had increased:

I think it's - it's become more about we need to hit numbers now... they don't take into consideration what we are. But I think a lot of that is to do with that structural management change that happened some time ago. The previous management understood what we were all about and how we did it. And that's been lost somewhere in the ether... I don't have the resource and funds available just to - to go out and spend $x$ amount on bringing in additional bodies to hit targets and things and you know. So it's - it's been difficult these last six months.

(Project Manager 3, Rural, 2015a)

Overall, though, Project Manager 3 was positive about what the Empty Homes project had achieved, even if the demands on his time as a manager were challenging.

A degree of trust and familiarity had developed and was in existence prior to the partnership, although an element of risk was present and interpersonal relationships were developed along the way as managers learned about each other's organizations, cultures and working methods. This aspect was important due to (1) reported challenges in the early years of the partnership, particularly resulting from the incremental financing and associated effect upon resources, as well as from imbalances due to differences in size and the availability of resources between the partner organizations; and (2) because, although all of the organizations collaborated willingly, no contract existed to legally bind them to it.

However, whilst this aspect was important in the successful management of tensions, we also discovered that tensions appeared to increase as a result of the departure of certain key individuals that had been involved in the formation of 
the collaboration and who had championed the original informal, "proactive" approach. A significant development prior to Phase 2 of our study appears to have been the departure of Council's Empty Homes Officer, an original participant in the collaboration and our study, who was clearly well regarded by the other organizations. One participant considered this key event to be a loss to the collaboration because he had been very effective at getting landlords to sign up to the scheme quickly (CEO, Urban 2015 Focus Group). Additionally, the Service Charge Manager of Coast who had participated in the research during the early stages of the collaboration was no longer involved. Another participant described this change as a loss because she had been "very much a can-do person" and it now felt as though there were more noticeable "bureaucratic barriers" (Craft-coordinator/ Director, Urban, 2015 Focus Group).

\section{The Role of Values and Ethics in Overcoming Tensions and Challenges}

When analysing our data to explain why the four partner organizations were willing to collaborate, we found clues as to the compatibility of their ethics and values and those of key decision-makers within the collaboration, and how they manifested as judgements and actions. In particular, a focus on end-users and social impact at community level was an important underpinning to the work of the partnership (i.e. the social welfare logic). Coast's main purpose as an organization was to provide housing, but its Head of Tenant Services who first initiated the Empty Homes partnership sought to extend the partnership beyond basic obligations by adding value to its offering by addressing the broader needs of its residents, i.e. improving employment prospects and reducing crime and anti-social behaviour. This collaboration had occurred at a time when the ethos of the local authority had also changed towards regeneration, and there was " $a$ real buy-in to try and help people" (Empty Homes Officer, Council, July 2012).

The community focus was even more emphasized within the smaller partners, which had a track record of integrating construction training and housing provision and thus provided a significant contribution to the partnership. Since the beginning of our research, the CEO of Urban referred to their "client focus" on "marginalized" young people (Dec 2011 and April 2012), which was corroborated by the other partners. Respondents from Rural also referred to the work they did beyond just housing people, including their contribution to the community - they emphasized their core work was constructing building works for community centres, church and village halls, and so on (Project Manager 1, Rural, 2012).

Similarities between Urban and Rural were not surprising given the fact Urban was involved in the original establishment of Rural and its CEO still retained a place on Rural's Board of Trustees. There were though subtle differences for much of the time that the research was undertaken. Rural placed most emphasis on engagement and the learning process of the young people it employed and trained; where Urban put additional emphasis on employment as well as engagement. Urban was proud that it trained young people who would otherwise not have had the opportunity:

They weren't the cream of the crop... a big chunk of them were people who were way beyond in distance from a trade. But we can still give them something from it.

(Development Manager, Urban, 2015)

However, the employability aspect was also mentioned later in the research by Rural (Project Manager 3, Rural, 2015) suggesting an increased emphasis on this aspect, perhaps learned from Urban, or perhaps simply due to the change in manager.

Overall, the belief in helping people was clearly an important part of the ethos of key individuals from all organizations within the partnership, particularly the founding members from the local authority (Empty Homes Officer, Council, 2012) and Coast (Head of Tenant Services, 2012; Service Charge Manager, 2012), and all the respondents from Urban and Rural throughout the period of our study. This people-oriented hybridity was, therefore, a pivotal ethical stance that key decision-makers brought to the partnership.

However, balancing the 'people' and 'community' focussed motives with the commercial push from the local authority and funders to spend the money and put rent-payers into 'empty' properties did cause tension. Despite the partnership's achievements for the community, as early as December 2012 two of the interviewees (Service Charge Manager, Coast, 2012; Project Manager 1, Rural, 2012) expressed some confusion about the future direction of the project. Perhaps not surprisingly, both ceased to be involved with Empty Homes within the period of our study. Their concerns were about the potential for opportunistic rentseeking behaviour from property owners who could receive a 'free' refurbishment and guaranteed rental income from their property by donating it to the Empty Homes initiative for a fixed-term of 5 years:

I don't think it's right...I think that money could be better spent by owning more of those empty properties... when we buy a property through Empty Homes money the property is going to stay with the Trust...we've got that property for the next tenants and the next.

Project Manager 1 (Rural, 2012)

This quote shows the potential tension between the social welfare and commercial logics in the management processes 
and the need for constant attention in the collaboration to resolve these tensions.

\section{The Expected and Unexpected Outcomes}

We have so far examined how the collaboration formed and operated, and determined how emergent tensions were mitigated. In order to understand whether these efforts were successful, we now examine the outcomes achieved by the partnership including both intended and unintended outcomes. Table 5 presents a framework summary of our synthesis by identifying the challenges, tensions, how these tensions were mitigated, and finally the outcomes of this hybrid collaboration.

The notion of social enterprises adding value compared to their commercial competitors has been comprehensively addressed in the social enterprise literature (Hockerts 2015; Mason and Doherty 2016), and featured extensively in our interviews. It was felt that, as social enterprises, Urban and Rural brought additional social benefits such as training schemes and helping vulnerable people who would otherwise have been so-called "hard to reach" groups, as far as Council was concerned. Incorporating the "worklessness agenda" (i.e. related to people out of work who are often "hard to reach") into the project has added value to the scheme, some of which is difficult to quantify (e.g. the impacts upon the future job prospects and improved quality of lives of the trainees). It is this community social impact that comes out strongly in Table 5 as a way of mitigating the tensions.

Since Phase 1 of the study, the collaboration was found to have aided quality assurance (working to nationally recognized social housing building standards); and being able to plan and to contribute to costs in other activities from the finances. Additionally, the training schemes have helped vulnerable and "hard-to-reach" people, and a local multiplier effect was perceived by one participant, although evidence was anecdotal rather than measured:

...the amount of money that we can bring in tens of thousands of pounds, can employ someone local - and it turns that money over. If we spend that money in local building supplier those local lads go and spend it in a pub, spend it in a shop, they buy things local, that money goes round. But if we spend it with a big supplier, the money just goes out of the area.

(Project Manager 1, Rural, 2012)

Similarly, Council perceived that the collaboration achieved community benefits, such as job creation, whilst also solving problems associated with derelict properties, or "bang for the buck" (Interview with former Empty Homes Officer, Council, 2012). The "value for money" achieved by the partnership's approach to the Empty Homes initiative was described as "Like three wins in one", specifically:

You're bringing an empty home back into use, so you're improving the environment for the rest of the people on that estate. You've got extra affordable housing to keep people out of bed and breakfast, and it's necessary to keep people off the waiting list, and that's who gets the houses at the end of the day. And then you've got three; the work element, which is jobs, training and employment. So its three wins for one piece of money, it's just nonsense not to do it.

(Head of Tenant Services, Coast, 2012)

The project has also produced unexpected benefits to the various partners, the most significant of which is arguably the national recognition received and subsequent publicity generated: leading to a huge array of joint opportunities and recognition, which were important factors in mitigating tensions. Further unexpected benefits included: successful applications for further funding; enhanced reputation and influence; support and learning beyond project scope; better sites for training; additional properties to manage and rent out; and positive relationships with property owners. This analysis shows that both social welfare and commercial logics can be compatible within a cross-sector collaboration (see Table 5). Although the partnership can be considered to have been for the most part successful during the time of our study, several challenges have emerged. First, properties have become harder to obtain: raising questions as to the sustainability of the project. Second, operational, budgeting and procurement challenges stemming from resource and expectation asymmetries, and differing priorities in regard to hybrid objectives, appear to relate to the mix of different sized organizations involved in the collaboration (see tensions in Table 5).

These challenges and achievements were all evident at all phases of our study, and at Phase Three we probed more deeply as the project ended and made some significant findings. This Empty Homes collaboration served as a catalyst for the others across the sub-region, some of which involved one or more of the original four participants. Individual organizations also experienced growth in activity. However, achieving this accelerated growth was not always easy as we have already mentioned. Considering how they might undertake similar projects in future, the CEO of Urban highlighted the need to have more structured project control and to be more reflective when completing renovations before "rushing to the next job", and suggested action research as a useful approach (CEO, Urban, 2015). Increasing its asset base helped Urban to fulfil hybrid objectives: from a commercial perspective, the increased housing stock represented an increased asset base against which it could borrow more money if necessary in future, or sell at an increased price 
once renovated; from a social welfare perspective, the organization housed and trained more people, and crucially to support people into longer-term employment.

Having evidenced our findings with rich data from the management within the collaboration, it is useful to refer also to the respondent from the Regional Office of the HCA who summarized the success of Empty Homes more broadly, reflecting its effectiveness in Council's area:

It started from $£ 250,000$ and 11 properties to the point now where [Coast] are buying up empty office blocks and converting them into residential units. So, the scale and the challenge, or the opportunity, has increased massively from doing one or two bed semidetached properties to tackling the town centre derelict office block.

(Senior Area Manager, HCA, 2015)

Our case, a quadripartite collaboration involving three hybrid organizations and a local government authority, shows how new approaches (in the UK, at least) to tackling 'wicked problems', such as homelessness and unemployment, can produce social impact as well as improving capacity within the SE sector. We now progress to a broader discussion of the practical and theoretical implications of our findings.

\section{Discussion}

We have presented a rich longitudinal case, exploring and explaining the challenges and tensions of a hybrid collaboration. We believe that our focus on a longitudinal (6-year period) multiple hybrid collaboration contributes to the literatures on social enterprise and hybrid organizing (Battilana et al. 2015) and cross-sector collaboration (Bryson et al. 2015). Our principal focus has been upon the management processes and especially how tensions have been mitigated and thus successfully overcome dynamically, which our extended study has enabled us to capture (see Table 5).

The collaboration of partners is a temporary organization based on an informal agreement with no explicit contract in place. We found that the successful temporary social housing grant application served as an initial key driver but does not appear to be referred to by the partners very often, instead the collaboration works on the shared belief by individuals in each organization of the importance of the social "mission" and its associated accountabilities and outcomes including: to provide housing, improve neighbourhoods, to create training and employment opportunities for young people, and in general to improve local communities and quality of life coupled with their commitment to meeting the financial requirements necessary to sustain the partnership and their own organizations i.e. the dual-mission. This builds on the call by Bryson et al. (2015) to provide more studies on the nature and importance of public value in cross-sector collaboration. It is clear in this hybridized collaboration that the resulting public value in the form of social impact mitigates the tensions created by the different prioritization of the social welfare and commercial logics plus the differing resource bases brought about by organizational size. It is clear the collaborative processes of shared social mission, trust and regular face-to-face meetings to create the spaces for negotiation are key in building both the partnerships social impact (public value) and overcoming the tensions as outlined in Table 5.

Despite frustrations and challenges arising from the differences between the organizations, the social impact achieved by the partnership should be viewed as evidence of its competence-indeed, competencies and capabilities of the smaller social enterprise organizations appear to have developed as a direct result of the Empty Homes work, as have their asset bases and capacity to house and train more people. We conclude this aspect is because the overlap of perspectives amongst the mix of partner organizations has resulted in synergies that could not have been achieved by any of those organizations independently. All benefited from the tangible (i.e. capital equipment) but more significantly the intangible (i.e. expertise) value that each partner brought to the network. The overlap of perspectives and the inclusion of hybrid organizations facilitated partnering and novel solutions to social challenges in this case. Also important here is the dynamic interaction of leadership and informal governance underpinned by a learning and adaptive culture. The positive publicity and public relations opportunities that the Empty Homes initiative presented for each partner, demonstrates the external legitimacy of the case. However, it was evident how the larger organizations were able to benefit most from this due to their size and available resources, whereas the SEs found it difficult at times to contribute to or capitalize from publicity opportunities because they were already somewhat stretched. We aim to bring the reader's attention to the fact that, unlike some other articles (Lyon and Fernandez 2012) which oversimplify or idealize the complex reality of relational working, we identify the partnership as itself a hybrid comprised of hybrids, and that each partner organization faces its own challenges and objectives. Specifically, the smaller partners (the SEs) placed greater weighting on the process of delivering the training and education element of Empty Homes, whereas the larger partners (local authority and the larger ex-local authority housing association) placing greater weighting on outputs such as the quantity of residential properties "created", and the quantity of people trained rather than considering qualitative measures. Despite this finding, the resulting social impact created mitigates any possible mission drift in the smaller SEs (see Table 5). 
We wish to acknowledge the exploratory nature of our study and have focussed mainly upon the hybridity and tensions at the managerial and operational level of the case. However, emerging from our findings is the importance of institutional logics. For example, the study of institutional logics in construction and engineering projects involving partner organizations from different sectors and contexts has recently become a popular line of inquiry. Scott (2011) proposes that institutional perspectives can help inform and guide decision-making by important project stakeholders in the built environment and infrastructure development, including "governments, oversight bodies, consumers of services, community members, and interest groups" (p. 8). This broader sociological institutional perspective has been applied to global projects, e.g. infrastructure development, but with few exceptions (e.g. Gillett and Tennent 2017, 2018), these investigations have tended to ignore the planning, delivery and legacy of regional or sub-regional crosssector collaborative projects. Neither does the literature deal sufficiently with cases in which hybrid partners such as social enterprises play a significant role, or recognize the importance of the values and ethics of organizations or individual managers within such social alliances.

The longitudinal study in this paper builds on the work of Hockerts (2015) by showing that both social welfare and commercial logics can be compatible in a hybrid collaboration not just at an individual organizational level. Moreover, we also contribute to the work on institutional logics by providing an alternative analysis to the most powerful imposing their logic on collaborations (Thornton and Ocasio 1999; Schuman 1995; Thornton 2004). Urban, in particular, exerted a relatively strong influence on the collaborationdespite having less obvious power than the larger organizations. This shows the importance of dynamic persistence of the smaller SEs by engaging in the 'spaces of negotiation' as well as delivering on social impact and illustrates that social welfare and commercial logics do not have to be in conflict.

The sociological definitions of institutional logics contain several important assumptions. Those pertinent to this study include: the importance of factors such as the background and experience of key people (Lok 2010), in some cases, one logic can be so dominant that any other logic does not impact organizational functioning but, in some cases, multiple logics can be so similar that they blend to provide a similar set of practices, values, ethics and beliefs (Greenwood and Suddaby 2006). Also, the assumption that actors can influence how logics are represented in organizations (Thornton and Ocasio 1999). In our longitudinal case, the importance of pre-existing relationships in tension mitigation appears to support the work of Lok (2010) regarding the background of individuals. Furthermore, the importance of actors in our case i.e. those 'bridging agents' is key to tension mitigation particularly in the early stages of our hybrid collaboration.
In relation to multiple logics and organizational functioning, we now discuss compatibility and centrality.

According to Besharov and Smith (2014), multiple logics within organizations possess two critical dimensions. First, compatibility, the extent to which the presence of multiple logics within an organization implies consistent organizational actions. Second, centrality, the extent to which logics manifest in core features which are central to organizational functioning. Some organizations can embody two or more logics in a relatively compatible fashion and these logics may ultimately blend to create new organizational forms (Rao et al. 2005). Consistency regarding organizational goals is most important for compatibility as goals reflect core values and beliefs. Compatibility is lower when there is tension regarding organizational goals. Organizational practices and characteristics such as hiring and socialization policies influence what type of logics are carried by the staff team (Battilana and Dorado 2010). Furthermore, close relationships between people can also result in increased motivation to develop more compatible approaches to enacting multiple logics (McPherson and Sauder 2013). In our empty homes case, the importance of both the shared social mission and asset development in tension mitigation shows the importance of high compatibility of logics.

Centrality is the extent to which one or more logics is core to organizational functioning. Centrality is hence higher when multiple logics are present in core organizational features which are central to organizational functioning and lower when a single logic guides core operations whilst other logics manifest in peripheral activities not directly linked to core organizational functioning (Besharov and Smith 2014). In our study we found that both social and commercial logics were important in the success of the collaboration and central to the organizational functioning, hence demonstrating a high level of centrality. This is key to organizational functioning in our collaboration, the focus on quality of social impacts plus commercial development appears to mitigate tensions around which logic is more important.

Our 6-year longitudinal study allows a temporal run of data to analyse the evolution and legacy of hybrid collaborations over the medium- to long-term. Authors such as Langley (1999) call for a processual research approach to chart events, activities, and choices, and the involvement of individuals and organizations to ascertain the sequence of events and dynamics among the various actors as they interpret and react to events in hybrid collaborations (Langley 1999). Furthermore, prior studies (e.g. Tennent and Gillett 2016; Gillett and Tennent 2017,2018) call for more archival organizational history research to be undertaken to enrich understanding of collaborative projects. We, therefore, agree that it would be apposite to conduct more research into the relationships between our collaborative partners that pre-dated the social alliance that we 
studied: Identifying relational bonds and path dependencies stemming from the prior history of collaborations could enable more accurate cases in comparison to those which focus only on the collaboration itself. Specifically, the following questions emerged from our findings:

How do institutional logics (and their influence on values and ethics) affect the initial motives of each organization for participating in the social alliance?

How do sectoral (e.g. public, private, or third sector) cultures affect the relationship dynamics within social alliances? In what ways are resulting conflicts and tensions resolvable, or if they are not resolvable, then why?

To what extent are relationship dynamics and the ability to mitigate tensions bound by the values and ethics of these organizations?

How do the various institutional factors affect the perceived legacy of social alliances? Is legacy perceived differently by different stakeholder groups depending upon their sectoral cultural attitudes, beliefs, values and ethics?

Orr, Scott, Levitt, Artto, and Kujala (2011) identify leadership, teamwork, and risk management as areas for future research. Therefore, to what extent does a shared culture develop within a hybrid collaboration encompassing public, private and third sector organizations? How long does this take to achieve good performance and how can it be accelerated? How can the quality of societal outputs be optimized, and do any differences in institutional logics, organizational values and/or managers' ethical beliefs serve to diminish or enhance the project?

Additionally, broader lines of inquiry emerge from our findings which could also prove fruitful areas of further research. One possible direction could be to explore the significance of "bridging agents" (Manning and Roessler 2014) and other key individuals to other "hybrid of hybrids' social alliances. Our study has provided some findings to support their importance, specifically the Senior Area Manager of the HCA and the Empty Homes Officer of Council, who were crucial in getting the partnership started. Future research could be to examine the role of bridging agents and other 'founder member' individuals to the sustainability of such partnerships. Our findings showed that when the Bridging Agent from Council changed career the informal approach to the partnership worked less smoothly, but this also corresponded with the departure of certain other 'key' individuals who had been involved since the start of the arrangement. Future research could, therefore, study the importance of social capital and pre-existing networks, and also the influence of personal ethics. Such a research agenda could potentially generate solutions for improving the likelihood of retaining the dedication and participation of key personnel, or for managing the transition period as individuals leave and join the partnership.
Another direction could be to further the work of Cornelius and Wallace (2010) and Wren Montgomery et al. (2012), by asking to what extent can a partner organization synchronize with the hybrid objectives of its partners without losing focus of its own mission? Relatedly, at times our interviewees considered the differences between the collaborating organizations as strengths, at others as the cause of tension, so future research could explore the degree to which organizations can better plan for each other's needs at the start of a collaboration to mitigate these problems at the outset.

The research directions that we suggest should provide a rich stream of knowledge that builds upon the insights from this paper, thereby developing the themes that we have identified, and testing our assertions. Indeed, although our methodology has confirmed our study's rigour, we must acknowledge its limitations. Generalizing from our study could be difficult because of its relatively narrow focus (four organizations comprising a single case in a particular subregion), although we do believe that the depth of data, the broad mix of different size and type of organizations, the characteristics of the geographic context (which encompassed urban and rural areas) and the longitudinal nature of our study mitigate these limitations, at least in part, and we believe that we make a strong case for more research of such hybrid collaborations and of hybridity in temporary and project-based scenarios. We, therefore, recommend further research to investigate hybridized collaborations in other contexts and in other scenarios. Furthermore, our research design did not allow us to ascertain definitively whether the important or influential factors we identified in hybridized collaboration (shown in Table 5) are additive, or complementary, or are of equal salience. As such, we recommend further investigation to examine how the connectivity and dynamics of the factors aid the successful development of hybrid collaborations.

\section{Conclusions and Recommendations}

This study has focussed upon a case in which several hybrid organizations, each with their own hybrid logics worked in combination to create a social alliance that was itself typified by hybrid objectives. This complex scenario contributes to the existing literature which tends to oversimplify or idealize the complex reality of relational working. We identify the partnership in our case as itself a hybrid comprised of hybrids, and that each partner organization faces its own challenges and objectives. To describe this 'hybrid of hybrids' we introduced the term hybrid collaboration.

The findings of this study have developed our understanding of the different forms of collaborative organizations, and how they faced both intended and unintended consequences 
from the collaboration. For example, the Empty Homes project generated considerable but unexpected publicity for all the participant organizations; whilst creating both opportunities and demands, these varied for each organization. In this Empty Homes collaboration both social and commercial logics are core to making the hybridized collaboration work, which shows the broad agreement across the four organizations regarding the organizational goals of community impact and building up the asset base and, therefore, the goals are compatible. The shared values ethics and beliefs related to community social impact, clearly exert a powerful mitigation over the tensions of resource base differences. This compatibility is key to mitigating the tensions in this collaboration. Furthermore, as both social and commercial logics are important to making this collaboration working there is also a high level of centrality demonstrated. Hence this Empty Homes collaboration could be termed 'aligned' (Besharov and Smith 2014). In addition, the synergy created from sharing resources is also important in this collaboration (Bryson et al. 2015; Smiddy 2010).

Our Table 5 framework analyses the tensions and how these are mitigated and provides a useful tool for those managers and academics either working in or researching crosssector collaborations involving hybrids. Previous work on hybrid tensions has been mainly focused at the individual organizational level so this study makes an important contribution to emerging but limited work on how tensions arise and how they are mitigated in collaborations. On a cautionary note the study also shows the dynamic nature of this collaboration and that constant focus is required to manage and mitigate the tensions. Phase 3 of the research shows that when individuals leave the collaboration for career reasons, the influence of pre-existing relationships reduces. This is where ongoing work to manage the tensions is vital.

We acknowledge that the ability to extrapolate the findings of our study to wider populations is limited due to our study focusing in depth on four organizations comprising a single case but we do believe the depth of data, the broad mix of different size and type of organizations, the characteristics of the geographic context (which encompassed urban and rural areas-as implied by the names we have used to anonymize the organizations within the collaboration) and the longitudinal nature of our study go some way to mitigating these limitations. We recommend further research to investigate hybridized collaborations in other scenarios, and to conduct more research underpinned by institutional theory, to assess the extent to which the institutional logics of the collaborative partners influenced their behaviours and actions, and the extent to which these logics hindered or aided the alliance. We also identified the opportunity for longitudinal and organizational history studies to deepen understanding of relational bonds and path dependencies in collaborative projects. Further research should also be undertaken to ascertain whether the factors we identify for successful hybridized collaboration are additive, or complimentary, or are of equal salience, and the extent to which they are dynamic. Finally, we have also identified the significance of values and ethics in overcoming challenges and tensions within our quadripartite hybrid collaboration, which also indicate lines of inquiry for further research (Cornelius and Wallace 2010; Wren Montgomery et al. 2012) in relation to the organizations and also to the people that made the collaboration work, which can be considered to be the 'bridging agents' (Manning and Roessler 2014).

Funding The workshops in this study were funded by an Economic Social Research Council (ESRC) Impact Accelerator Grant awarded by the University of York.

\section{Compliance with Ethical Standards}

Conflict of interest Dr Alex Gillett declares that he has no conflict of interest. Dr Kim Loader declares that she has no conflict of interest. Professor Bob Doherty declares that he has no conflict of interest. Dr Jonathan M. Scott also declares that he has no conflict of interest.

Open Access This article is distributed under the terms of the Creative Commons Attribution 4.0 International License (http://creativeco mmons.org/licenses/by/4.0/), which permits unrestricted use, distribution, and reproduction in any medium, provided you give appropriate credit to the original author(s) and the source, provide a link to the Creative Commons license, and indicate if changes were made.

\section{References}

Andrews, R., \& Entwistle, T. (2010). Does cross sectoral partnership deliver? An empirical exploration of public service effectiveness, efficiency and equity. Journal of Public Administration Research and Theory, 20(3), 679-701.

Austin, J. (2010). The collaboration challenge. How non-profits and businesses succeed through strategic alliances. San Francisco: Jossey Bass.

Austin, J., Stevenson, H., \& Wei-Skillern, J. (2006). Social and commercial entrepreneurship: Same, different or both? Entrepreneurship Theory and Practice, 30(1), 1-22.

Austin, J. E. (2000). The collaboration challenge: How nonprofits and business succeed through strategic alliances. San Francisco: Jossey-Bass.

Battilana, J., \& Dorado, S. (2010). Building sustainable hybrid organizations: The case of commercial microfinance organizations. Academy of Management Journal, 53(6), 1419-1440.

Battilana, J., Sengul, M., Pache, A., \& Model, J. (2015). Harnessing productive tensions in hybrid organizations: The case of work integration social enterprises. Academy of Management Journal, 58(6), 1658-1685.

Berger, I. E., Cunningham, P. H., \& Drumwright, M. E. (2006). Identity, identification, and relationship through social alliances. Journal of the Academy of Marketing Science, 34(2), 128-137.

Besharov, M. L., \& Smith, W. K. (2014). Multiple institutional logics in organizations: Explaining their varied nature and implications. Academy of Management Review, 39(3), 364-381. 
Billis, D. (2010). Towards a theory of hybrid organizations. In D. Billis (Ed.), Hybrid organizations and the third sector (pp. 46-69). Basingstoke: Palgrave Macmillan.

Binder, A. (2007). For love and money: Organizations creative responses to multiple environmental logics. Theory and Society, 36(6), 547.

Brandsen, T., \& Karré, P. M. (2011). Hybrid organizations: no cause for concern? International Journal of Public Administration, 34(13), 827-836.

Bryson, J. M., Crosby, B. C., \& Stone, M. M. (2015). Designing and implementing cross-sector collaborations: Needed and challenging. Public Administration Review, 75(5), 647-663.

Cairns, B., \& Harris, M. E. (2011). Local cross-sector partnerships: Tackling the challenges collaboratively. Nonprofit Management and Leadership, 21(3), 311-324.

Coast (2013). Annual Report and Financial Statements.

Corbin, J., \& Strauss, A. (1990). Grounded theory research: Procedures, canons and evaluative criteria. Zeitschrift Fur Soziologie, 19(6), 418-427.

Cornelius, N., \& Wallace, J. (2010). Cross-sector partnerships: City regeneration and social justice. Journal of Business Ethics, 94(Supplement 1), 71-84.

Czischke, D., Gruis, V., \& Mullins, D. (2012). Conceptualising social enterprise in housing associations. Housing Studies, 27(4), 418-437.

Davies, I. A. (2009). Alliances and networks: Creating success in the UK fair trade market. Journal of Business Ethics, 86(1), 109-126.

Dew, N. (2009). Serendipity in entrepreneurship. Organization Studies, 30(7), 735-753.

Di Domenico, M.-L., Haugh, H., \& Tracey, P. (2010). Social bricolage: Theorizing social value creation in social enterprises. Entrepreneurship Theory and Practice, 34(4), 681-703.

Doherty, B., Haugh, H., \& Lyon, F. (2014). Social enterprises as hybrid organizations: A review and research agenda. International Journal of Management Reviews, 16(4), 417-436.

Eisenhardt, K. M. (1989). Building theories from case study research. Academy of Management Review, 14(4), 532-550.

Galaskiewicz, J., \& Colman, M. S. (2006). Collaboration between corporations and nonprofit organizations. In W. Powell \& R. Steinberg (Eds.), The nonprofit sector. A research handbook (pp 180-204). New Haven: Yale University Press.

Gillett, A. G., Loader, K. E., Doherty, B., \& Scott, J. M. (2016). A multi-organizational cross-sectoral collaboration: Empirical evidence from an 'Empty Homes' project. Public Money and Management, 36(1), 15-22.

Gillett, A. G., \& Tennent, K. D. (2017). Dynamic sublimes, changing plans, and the legacy of a megaproject: The case of the 1966 Soccer World Cup. Project Management Journal, 48(6), 93-116.

Gillett, A. G., \& Tennent, K. D. (2018) Shadow hybridity and the institutional logic of professional sport: Perpetuating a sporting business in times of rapid social and economic change. Journal of Management History, 24:228-259

Glaser, B. G., \& Strauss, A. L. (1967). The discovery of grounded theory. Chicago: Aldine.

Gray, B., \& Stites, J. P. (2013). Sustainability through partnerships: capitalizing on collaboration. Network for business sustainability. https://www.nbs.net/knowledge. Accessed 26 May 2016.

Greenwood, R., \& Suddaby, R. (2006). Institutional entrepreneurship in mature fields: The big five accounting firms. Academy of Management Journal, 49(1), 27-48.

Hansmann, H. (1980). The role of non-profit enterprise. Yale Law Journal, 89(5), 835-901.

Hardy, C., \& Phillips, N. (1998). Strategies of engagement: Lessons from the critical examination of collaboration and conflict in an interorganizational domain. Organization science, 9(2), 217-230.
HCA. (2013). Homes and communities agency: About us. What we do. https://www.gov.uk/government/organisations/homes-and-commu nities-agency/about. Accessed 23 Mar 2016.

Hockerts, K. (2015). How hybrid organizations turn antagonistic assets into complementarities. California Management Review, 57(3), 83-106.

Hodge, A. G., \& Greve, C. (2007). Public-private partnerships: An international performance review. Public Administration Review, 67(3), 545-558.

Horton, D., Prain, G., \& Thiele, G. (2009). Perspectives on partnership: A literature review. International Potato Center. http://cipotato. org/publications/perspectives-on-partnership-a-literature-review/. Accessed 29 May 2016.

Hustinx, L., Verschuere, B., \& De Corte, J. (2014). Organisational hybridity in a post-corporatist welfare mix: The case of the third sector in Belgium. Journal of Social Policy, 43(2), 391-411.

Huxham, C. (1993). Pursuing collaborative advantage. The Journal of the Operational Research Society, 44(6), 599-611.

Jay, J. (2013). Navigating paradox as a mechanism of change and innovation in hybrid organizations. Academy of Management Journal, 56(1), 137-159.

Jones, C., \& Dunn, M. B. (2007). Careers and institutions: the centrality of careers to organizational studies. In H. Gunz \& M. Peiperl (Eds.), Handbook of career studies (pp. 437-450). Los Angeles: Sage.

Kickert, W. J. M. (2001). Public management of hybrid organizations: Governance of quasi-autonomous agencies. International Public Management Journal, 4(2), 135-150.

Kolk, A., \& Lenfant, F. (2015). Cross-sector collaboration institutional gaps and fragility: The role of social innovation partnerships in a conflict affected region. Journal of Public Policy and Marketing, 34(2), 287-303.

Langley, A. (1999). Strategies for theorizing from process data. Academy of Management Review, 24(4), 691-710.

Lok, J. (2010). Institutional logics as identity projects. Academy of Management Journal, 53(6), 1305-1335.

Lyon, F. (2012). Social innovation, co-operation, and competition: Inter-organizational relations for social enterprises. In A. Nicholls \& A. Murdock (Eds.), Social innovation: Blurring boundaries to reconfigure markets (pp. 139-161). Basingstoke: Palgrave MacMillan.

Lyon, F., \& Fernandez, H. (2012). Strategies for scaling up social enterprise: Lessons from early years providers. Social Enterprise Journal, 8(1), 63-77.

Manning, S., \& Roessler, D. (2014). The formation of cross-sector development partnerships: How bridging agents shape project agendas and longer-term alliances. Journal of Business Ethics, 123(3), 527-547.

Mars, M. M., \& Lounsbury, M. (2009). Raging against or with the private marketplace? Journal of Management Inquiry, 18(1), 4-13.

Martello, W. E. (1994). Developing creative business insights: Serendipity and its potential in entrepreneurship. Entrepreneurship and Regional Development, 6(3), 239-258.

Mason, C., \& Doherty, B. (2016). A fair trade-off? Paradoxes in the governance of fair-trade social enterprise. Journal of Business Ethics, 136(3), 451-469.

McPherson, C. M., \& Sauder, M. (2013). Logics in action: Managing institutional complexity in a drug court. Administrative Science Quarterly, 58(2), 165-196.

Moizer, J., \& Tracey, P. (2010). Strategy making in social enterprise: The role of resource allocation and its effects on organizational sustainability. Systems Research and Behavioral Science, 27(3), 252-266.

Morrison, N. (2016). Institutional logics and organisational hybridity: English housing associations' diversification into the private rented sector. Housing Studies, 31(8), 897-915. 
Mullins, D., \& Pawson, H. (2010). Housing associations: Agents of policy or profits in disguise. In D. Billis (Ed.), Hybrid organizations and the third sector (pp. 197-218). Basingstoke: Palgrave MacMillan.

Nicholls, A., \& Huybrechts, B. (2016). Sustaining inter-organizational relationships across institutional logics and power asymmetries: The case of fair trade. Journal of Business Ethics, 135(4), 699-714.

OED (Oxford English Dictionary) (2010) Edition. http://www.oed. com. Accessed 4 July 2012.

Orr, R. J., Scott, W. R., Levitt, R. E., Artto, K., \& Kujala, J. (2011). Global projects: Distinguishing features, drivers, and challenges. In W. R. Scott \& R. E. Levitt (Eds.), Global projects: Institutional and political challenges (pp. 15-51). Cambridge: Cambridge University Press.

Pache, A. C., \& Santos, F. (2012). Inside the hybrid organization: Selective coupling as a response to competing institutional logics. Academy of Management Journal, 56(4), 972-1001.

Ramus, T., \& Vaccaro, A. (2017). Stakeholders matter: How social enterprises address mission drift. Journal of Business Ethics, 143(2), 307-322.

Rao, H., Monin, P., \& Durand, R. (2005). Border crossing: Bricolage and the erosion of categorical boundaries in French gastronomy. American Sociological Review, 70(6), 968-991.

Ruef, M. (2000). The emergence of organizational forms: A community ecology approach. American Journal of Sociology, 106(3), 658-714.

Sakarya, S., Bodur, M., Yildirim-Öktem, Ö, \& Selekler-Göksen, N. (2012). Social alliances: Business and social enterprise collaboration for social transformation. Journal of Business Research, $65,1710-1720$.

Santos, F. M. (2012). A positive theory of social entrepreneurship. Journal of Business Ethics, 111(3), 335-351.

Santos, F. M., Pache, A.-C., \& Birkholz, C. (2015). Making hybrids work. California Management Review, 57(3), 36-58.

Scott, W. R. (2011). Introduction: Studying global projects. In W. R. Scott, R. E. Levitt \& R. J. Orr (Eds.), Global projects: Institutional and political challenges (pp. 1-12). Cambridge: Cambridge University Press.

Seitanidi, M. M., \& Crane, A. (2014). Social partnerships and responsible business: A research handbook. London: Routledge.

Seitanidi, M. M., Koufopoulos, D. N., \& Palmer, P. (2010). Partnership formation change: Indicators for transformative potential in cross sector social partnerships. Journal of Business Ethics, 139, $139-161$.

Selsky, J. W., \& Parker, B. (2005). Cross-Sector partnerships to address social issues: Challenges to theory and Practice. Journal of Management, 31(6), 849-873.

Simmons, R. (2008). Harnessing social enterprise for local public services: The case of new leisure trusts in the UK. Public Policy and Administration, 23(3), 278-301.
Smiddy, L. O. (2010). Corporate creativity: The Vermont L3C and other developments in social entrepreneurship. Vermont Law Review, 35(1), 3-14.

Smith, S. R. (2010). Hybridization and non-profit organizations: The governance challenge. Policy and Society, 29(3), 219-229.

Somerville, P., \& McElwee, G. (2010). Situating community enterprise: A theoretical explanation. Entrepreneurship and Regional Development, 23(5), 317-330.

Suchman, M. C. (1995). Managing legitimacy: Strategic and institutional approaches. Academy of Management Review, 20(3), 571-610.

Teasdale, S. (2010a). Explaining the multi-faceted nature of social enterprise: Impression management as social entrepreneurial behaviour. Voluntary Sector Review, 1(3), 271-292.

Teasdale, S. (2010b). Models of social enterprise in the homelessness field. Social Enterprise Journal, 6(1), 23-34.

Tennent, K. D., \& Gillett, A. G. (2016). Foundations of managing sporting events: organizing the 1966 FIFA World Cup. New York: Routledge.

Thornton, P. H. (2004). Markets from culture: Institutional logics and organizational decisions in the higher education publishing. Stanford: Stanford University Press.

Thornton, P. H., \& Ocasio, W. (1999). Institutional logics and the historical contingency of power in organizations: Executive succession in the higher education publishing industry 1958-1990. The American Journal of Sociology, 105(3), 801-843.

Thornton, P. H., \& Ocasio, W. (2008). Institutional logics. In R. Greenwood, C. Oliver., R. Suddaby. \& K. Sahlin Andersson (Eds.), Handbook of organizational institutionalism (pp. 100-129). London: Sage.

Tracey, P., \& Jarvis, O. (2007). Toward a theory of social venture franchising. Entrepreneurship Theory and Practice, 31(5), 668-685.

Tracey, P., Phillips, N., \& Jarvis, O. (2011). Bridging institutional entrepreneurship and the creation of new organizational forms: A multilevel model. Organization Science, 22(1), 60-80.

Van Tulder, R., Seitanidi, M. M., Crane, A., \& Brammer, S. (2016). Enhancing the impact of cross-sector partnerships: Four impact loops for channelling partnership studies. Journal of Business Ethics, 135(1), 1-17.

Wilson, F., \& Post, J. E. (2013). Business models for people, planet (\& profits): Exploring the phenomena of social business, a marketbased approach to social value creation. Small Business Economics, 40(3), 715-737.

Wren Montgomery, A., Dacin, P. A., \& Dacin, T. M. (2012). Collective social entrepreneurship: Collaboratively shaping social good. Journal of Business Ethics, 111(3), 375-388. 